\title{
Discrete Fourier Transform and Cepstrum Analysis of Vibration Events on Semi-trailer Truck
}

The aim of this paper is to present a novel techniqe to analyse the vibration signals during transportation in order to give new information to engineers to better understand these physical events. One of the primary sources of damages during transportation is the permanent vibration transmitted from the platform of semi-trailer to the cargo. The nature of this vibration depends on the road conditions and the features of the vehicle. In this study, a 2-axle-truck with a 3-axle-semi-trailer equipped with air spring suspension was observed to analyse the vibration circumstances. The affecting factors during the transportation were the type of the road (motorway, primary road, secondary road, tertiary road), and different vehicle speed levels. The vibration events were measured and registered on the platform of the trailer, then these values were evaluated in MATLAB environment. The presence of the harmonic vibrational components, the stationarity of the mode shapes, the characteristic frequency narrow-bands of the RMS and PSD values were primarily studied. The applied methods that were used are: discrete Fourier transformation, autocorrelation-, cross-correlation functions and cepstrum analysis.

Keywords: vibration, acceleration, discrete Fourier transformation (DFT), auto-correlation, cepstrum analysis

\section{INTRODUCTION}

Nowadays, the semi-trailer trucks carry out most of the mid- and long-haul road transports in the European logistics systems. On motorways, it can very often be observed that such vehicles are forming a continuous „train” while transporting goods. A certain part of them is carrying out the transports of industrial goods between different manufacturing plants, another part of them is carrying out the transports of finished goods in the industry-wholesale relation to the different logistic distribution hubs.

Insurance-related data, as well as own experiences confirm that these types of vehicles are relatively often involved in statistics on accidents. It happens even more often that the cargo and/or the transported packaged goods are damaged upon arrival at the place of destination. [1]

The great majority of the damaging to the goods can be discovered after arrival at the place of destination, in the course of unpacking of the goods. [2] The senders of the goods often protect against these damages by „overpackaging" the products, causing thereby considerable additional costs, furthermore in case of one-way packaging, also the environment will be polluted.

In this study, the objective was set to investigate the

Received: September 2018, Accepted: October 2018

Correspondence to: Peter Borocz, PhD, Associate

Professor, Szechenyi Istvan University (SZE)

Egyetem ter 1, Gyor, Hungary

E-mail: pidl.renata@ga.sze.hun

doi: $10.5937 /$ fmet1901177P

(C) Faculty of Mechanical Engineering, Belgrade. All rights reserved dynamical characteristics of these semi-trailer trucks. The semi-trailer of the truck can be considered such a special simply supported beam, the support of which from the side of the truck can be regarded as a 5 degrees-of-freedom vibration system. The 6th degreeof-freedom of the semi-trailer, the angular displacement related to the pitching will be eliminated, since its transmission is prevented by the technical construction of the fifth-wheel - kingpin structure [3]. The rear support will remain as 6 degrees-of-freedom vibration system on each axle that can transmit all kinds of vibrations through air springs and vibration dampers with progressive damping. As a result, it was experienced that some special vibration features of vehicles are not described in the literature.

Previous studies have already been conducted to measure and analyse these vibration levels, but were limited mainly to fast Fourier transformation (FFT) [48], and these did not analyse the vibration signal with discrete Fourier transformation (DFT), autocorrelation functions, or with cepstrum analysis.

\section{MEASURING CIRCUMSTANCES}

\subsection{Vehicle and cargo}

In order to analyse the vibration levels, the following truck, trailer and cargo were used (Figure 1).

Truck: Renault truck (280kW, DIESEL), semitrailer: WILKIEN Oldenburt, equipped with air spring suspension, cargo: returnable engine pallets. Total weight of the vehicle and cargo together was $30.674 \mathrm{~kg}$. 


\subsection{Transportation route}

The measurement was conducted on January 29, 2016 on roads in Györ-Moson-Sopron county in Hungary, duration of test was altogether 5 hours 30 minutes. Figure 2 and 3 show the route and speed levels of truck during measurement.

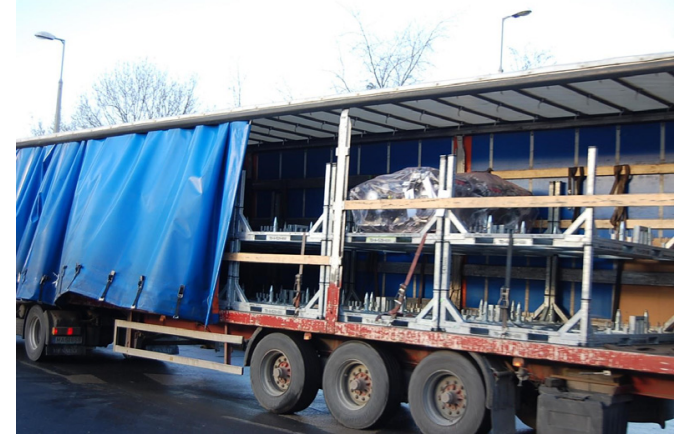

Figure 1. The semi-trailer and cargo observed during measurement

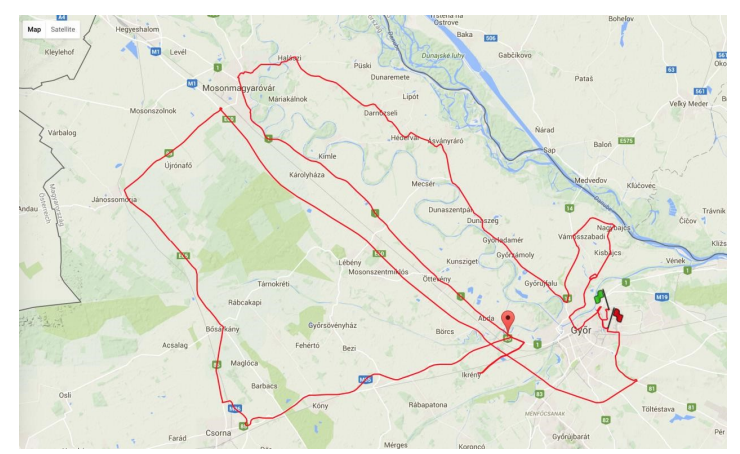

Figure 2. Shipping route measured

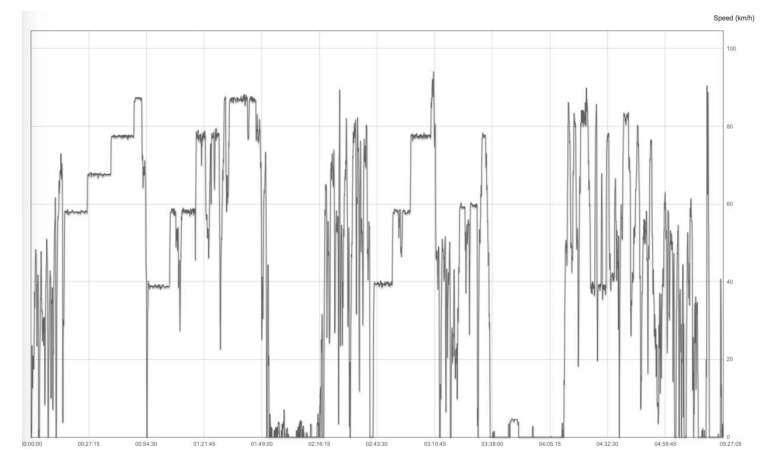

Figure 3. Running speed of truck (vertical axis: speed level, horizontal axis: time)

Table 1. Specification of travel events

\begin{tabular}{|c|c|c|c|c|}
\hline Start & End & $\begin{array}{c}\text { Road } \\
\text { identifier }\end{array}$ & $\begin{array}{l}\text { Speed } \\
(\mathrm{km} / \mathrm{h})\end{array}$ & $\begin{array}{c}\text { Road } \\
\text { quality }\end{array}$ \\
\hline $09: 55: 43$ & $10: 05: 42$ & Györ & $0-50$ & City road \\
\hline 10:11:03 & $10: 47: 00$ & M1 & $\begin{array}{l}60 \\
80\end{array}$ & Motorway \\
\hline $10: 50: 36$ & $11: 23: 57$ & 86 & $\begin{array}{l}40 \\
60 \\
80 \\
\end{array}$ & $\begin{array}{l}\text { Secondary } \\
\text { road }\end{array}$ \\
\hline $12: 37: 16$ & $13: 02: 55$ & 1 & $\begin{array}{l}40 \\
60 \\
80\end{array}$ & $\begin{array}{l}\text { Primary } \\
\text { road }\end{array}$ \\
\hline $13: 17: 47$ & $14: 3: 50$ & Szigetköz & $\begin{array}{l}40 \\
60 \\
80 \\
\end{array}$ & $\begin{array}{l}\text { Tertiary } \\
\text { road }\end{array}$ \\
\hline $14: 44: 37$ & 15:10:00 & Györ & $0-50$ & City road \\
\hline
\end{tabular}

To determine the averaged effect of the circumstances of transportation such as road condition during shipping, the truck travelled on various roads, such as motorways, primary roads, secondary roads, tertiary roads and city roads. The detailed specifications of the measurement are included in Table 1.

\subsection{Measuring device and setup}

The vibration events during the shipping process were measured for all three axes (vertical, lateral and longi-tudinal) using Lansmont (SAVER) ${ }^{\mathrm{TM}}$ 3X90 (Shock and Vibration Environment Recorder, Lansmont Corp., CA, USA) to collect the data. This device can be seen on Figure 4 .

For each segment of the measurement, the recorder was mounted directly to the floor and was located at the right rear of the vehicle cargo area.

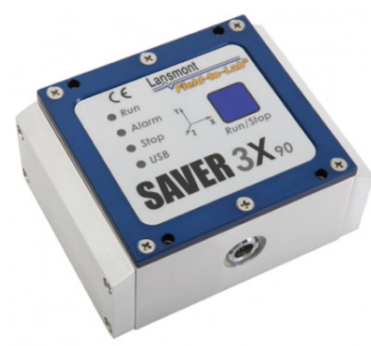

Figure 4. SAVER $3 \times 90$ date recorder device

The settings of the recorder used in this study are listed below.

- Timer trigger

- Length of recording: $1000 \mathrm{msec}$

- Sample / second: $500 \mathrm{~Hz}$

- Sample dimension: 1000

- Wakening frequency: $1000 \mathrm{msec}$

- Frequency breakdown to PSD: $1 \mathrm{~Hz}$ anti-aliasing filter frequency: $250 \mathrm{~Hz}$

- $\quad$ Examined frequency range: $1-200 \mathrm{~Hz}$

The device was switched on during the forming of the unit cargo of the manufacturing plant in Györ and it remained in this switched-on condition until the cargo returned to the manufacturing plant. The device, in all three directions, recorded the motion-like physical conditions.

The channel distribution of the SAVER:

- CH1: lateral or cross-direction

- $\mathrm{CH} 2$ : horizontal or longitudinal

- $\mathrm{CH} 3$ : vertical

\subsection{Data analysis}

In the case of vibration analysis, power density (PD) levels were determined first as a function of frequency based on the recorded random vibration acceleration levels as used by former researches [9] [10] [11].

The average power density within a narrow band of frequencies (BW) of a given spectrum can be determined by $G_{\text {rms }}$ values based on the number of samples of a given bandwidth. In this way, $G_{\mathrm{rms}}$ is determined by the root mean square value of the acceleration in G's in the given bandwidth of frequency, based on the number of (n) samples. 


$$
P D=\frac{1}{B W} \sum_{i=1}^{n}\left(R M S G_{i}^{2}\right) / n
$$

The vibration environment was then represented by the power density spectrum (PSD) showing a plot of the power density levels versus frequency. The energy within a specific frequency range can be obtained by integrating PSD within that frequency range and is usually represented in $\mathrm{G}_{\mathrm{rms}}$ for the entire or portion of the spectrum. The computation of PSD is done directly using the method called Fourier transformation or computing autocorrelation function and then transforming it to use as diagnostic method [12-13].

The stationarity of the recorded acceleration-time functions under identical road conditions and at identical running speed was examined by autocorrelation function.

The acceleration-time function was analysed by Cepstrum analysis that shows at which revolution number can be found such response revolution number, in case of which the frequencies arising from the difference of the two revolution numbers are half-harmonics of each other. Since the Cepstrum analysis is not generally known, therefore in Figure 5 it is demonstrated in a block diagram.

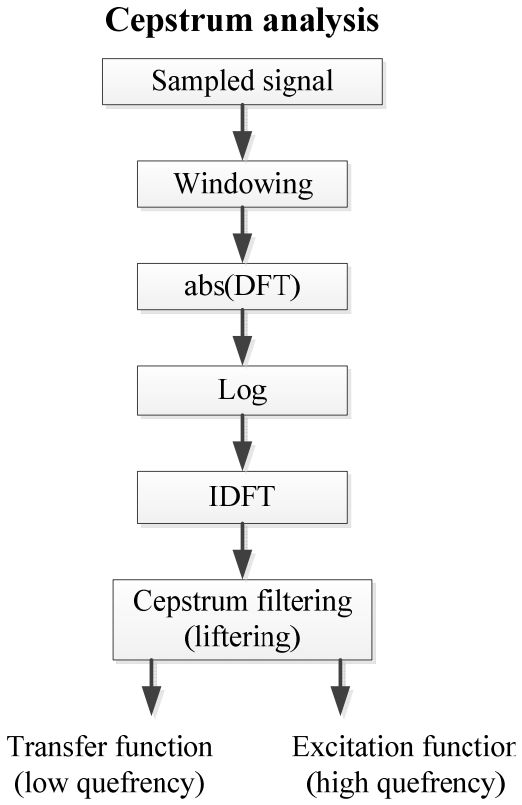

Figure 5. Overview of Cepstrum analysis

\section{EVALUATION OF RESULTS}

\subsection{Vibrations from the engine-powertrain-auxiliary drive system caused by unbalanced rotating masses}

The vibrations arising from the engine-powertrainauxiliary drive system of the truck are theoretically harmonic and this is very important from the point of view of the examination, because the harmonic excitation transmitted to the mass of the cargo may coincide with the eigenfrequency of the cargo and in this case resonance may occur. One of the accelerationtime functions recorded during running can be seen in Figure 6 .

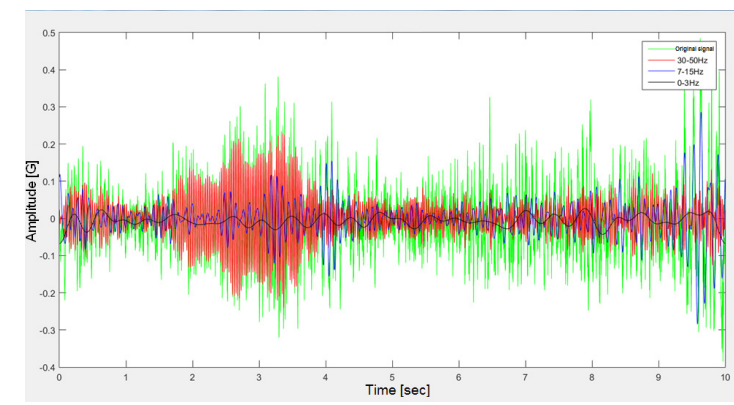

Figure 6. Acceleration-time function recorded during transport in unfiltered and filtered condition (green: original signal, red: $50-70 \mathrm{~Hz}$, blue: $7-15 \mathrm{~Hz}$, black: $0-3 \mathrm{~Hz}$ )

It can clearly be seen from Figure 6, that the signal is strongly stochastic and no sign hinting at harmonics can be found in it. With regard to this, the decision was made to run the engine of the truck at different throttle positions in a not-moving vehicle in order to see how the signal will be transmitted to the semi-trailer. This can be utilized to find out that during running in which ranges to search for harmonic signals in the stochastic signals.

The acceleration-time function registered in case of running engine in a not-moving vehicle and its power spectral density function can be seen in Figure 7 and 8 .

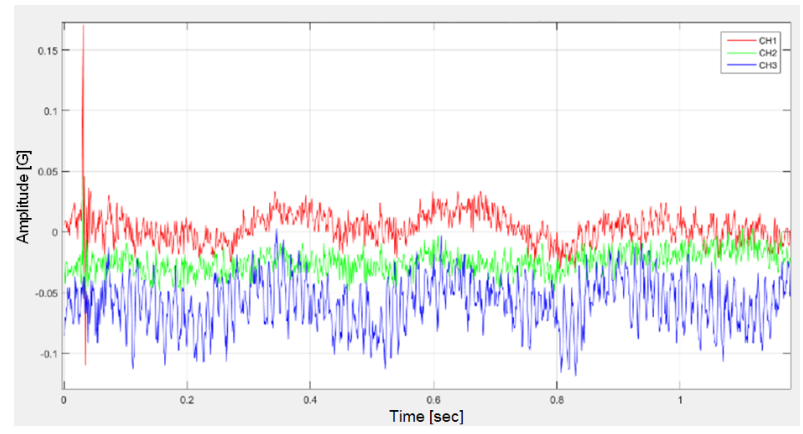

Figure 7. Acceleration-time function of a running engine in a not-moving vehicle (red: $\mathrm{CH} 1$ lateral, green: $\mathrm{CH} 2$ longitudinal, blue: $\mathrm{CH} 3$ vertical)

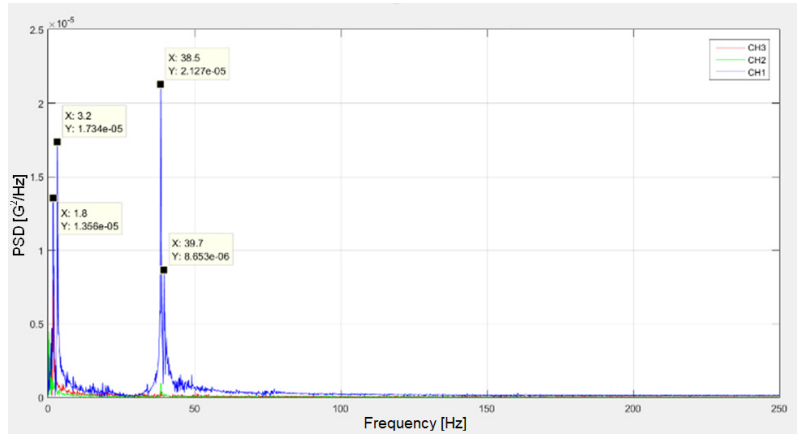

Figure 8. Power spectral density function of a running engine in a not-moving vehicle (red: $\mathrm{CH} 3$ lateral, green: $\mathrm{CH} 2$ longitudinal, blue: $\mathrm{CH} 1$ vertical)

From the above two figures the following can be established.

No pure harmonic excitation is transmitted from the truck to the platform of the semi-trailer due to the fact that the components of the engine-powertrain-auxiliary drive part system are rotating at different revolution number on one hand, while on the other hand their suspension is dampened and that is why no pure sinusoidal signals arise. 
In Figure 7, the acceleration sensor measuring the longitudinal and vertical vibration does not start from value zero. This is not an offset error, but the platform of the semi-trailer has got two different positions which can be adjusted by the pressures of the air spring. Either of the positions is the "loading" position, in case of which the platform is horizontal (so that the truck can be loaded from side by forklift), the other position is the dynamic one, in case of which the pressure of the air springs is adjusted in such a way that the semi-trailer is tilted backwards - depending on the load - by 1-3 degrees so that the smooth running and the fifth-wheelload can optimally be adjusted.

The lateral (cross-direction) versus time acceleration function does not start from value zero either, this is not an offset error either, but it is due to the sideward tilt of the roadway by 1-2 degrees due to water drainage.

The resulting PSD values are lower by one order of magnitude than the PSD values during running, illustrated later (Figure 9).

\subsection{The effect of running speed at same road condition}

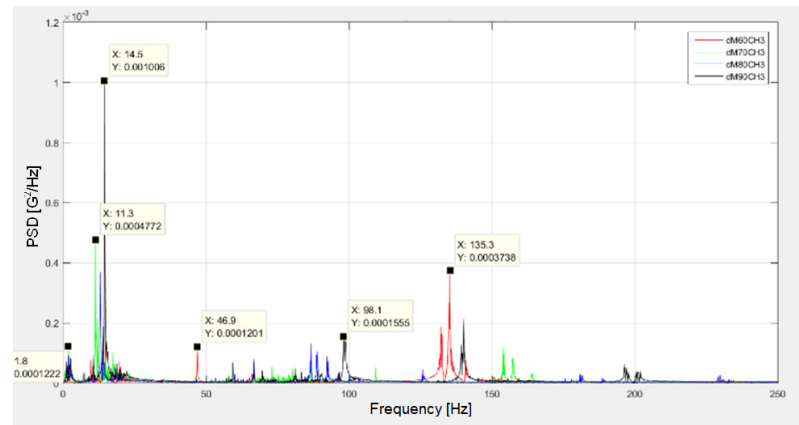

Figure 9. Synthesized vertical PSD function on identical road quality at different running speed (red: $60 \mathrm{~km} / \mathrm{h}$, green: $70 \mathrm{~km} / \mathrm{h}$, blue: $80 \mathrm{~km} / \mathrm{h}$, black: $90 \mathrm{~km} / \mathrm{h}$ )

\subsection{The effect of road condition at same vehicle speed}

As it can be seen from Figure 10, the poor quality of the road (from tertiary to motorway) increases the PSD values by 4.3-5.1 times, while the composition of the frequency remains almost unchanged.

By this measurement, it can be confirmed that the optimal running speed defined in point 3.2 is valid also for the different road qualities and is not identical with the maximum permitted running speed.

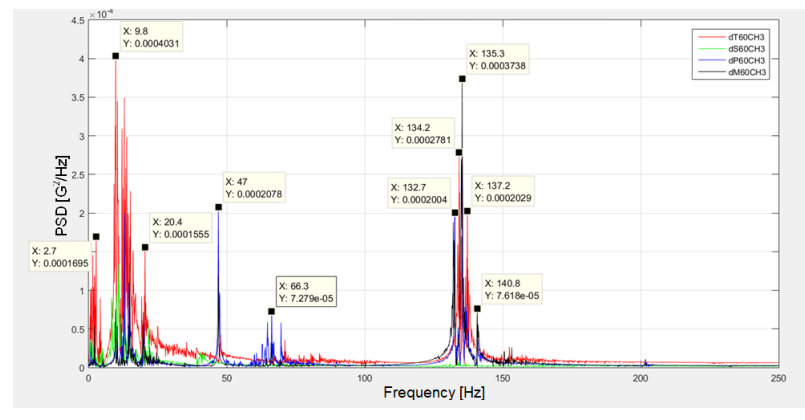

Figure 10. Comparison of vertical PSD $10 \mathrm{sec}$ long signals generated on different road qualities at running speed of $\mathbf{6 0}$ $\mathrm{km} / \mathrm{h}$ (red: tertiary road, green: secondary road, blue: primary road, black: motorway)

\subsection{Stationarity of acceleration-time function while running on identical road quality}

In practice, in case of vehicles running under identical road conditions and at identical speed, it is generally assumed that the signal - despite its stochasticity - is stationary. It has significance when at the vibration examinations of the packaging technology, the vibration simulation programs are producing identical exciting signals for such cases.

As a first approach, the autocorrelation functions were generated from the ,raw” acceleration-time functions and the figure of the autocorrelation function on one part, as well as the Pearson correlation coefficient on the other part have shown the complete independence of the auto-correlated signals. The assumption of identical road, identical running speed, and stationary signal is disproven by this fact.

The autocorrelation test was repeated with such modification that the signals of two separate accelerationtime functions were taken out as sample, the PSD function of both signals were made and the two PSD functions were auto-correlated. The result of this test can be seen in Figure 11 and 12.

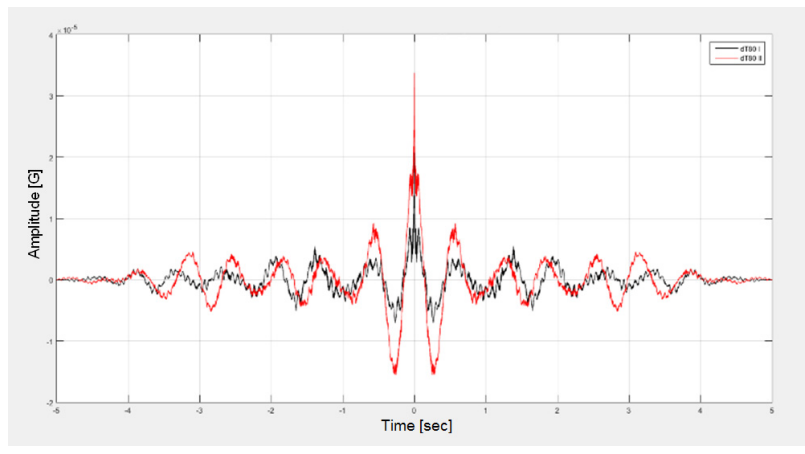

Figure 11. Autocorrelation function of two consecutive signal samples

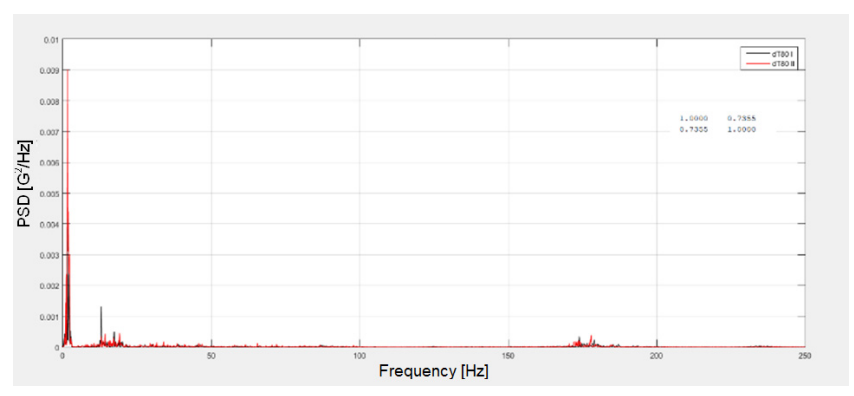

Figure 12. PSD plot of two consecutive signal samples

In case demonstrated in Figure 12, the value of the Pearson correlation coefficient is 0.73 , which is a medium correlation value and this can still be accepted from point of view of stationarity. In the rest of the cases of the investigation, the value of the Pearson correlation coefficient was much lower. This confirms that the assumption of stationarity is generally not true.

\subsection{Cepstrum analysis for the separation of the exciting and the response signals}

The cepstrum analysis is applied in the field of engineering mainly for discovery of errors of the rotating components. 
In order to obtain spectrums from the filtered cepstrums, the Fourier transform of the filtered cepstrum and then its exponential must be formed. So the spectrum of the transmission and that of the excitation can be obtained. If the phase values are kept, either the time-function of the transmission or the timefunction of the excitation can be recovered.

In Figure 13, the PSD recorded on motorway at speed of $80 \mathrm{~km} / \mathrm{h}$, while in Figure 14, the cepstrum function formed from it is demonstrated. From the cepstrum function, it can clearly be seen that the exciting signals can be found between values $0-0.2$ quefrency. Above this, no signals of significant maplitude value can be found in the function. Values of low maplitude can be found up to value of $5000 \mathrm{msec}$ quefrency. This phenomenon is true for all variants of acceleration-time functions that were recorded.

Two fundamental facts can be defined from these. First, in low frequency ranges $(0-15 \mathrm{~Hz})$, exciting signals can be found which are independent from each other. Second, in higher frequency ranges, the halfharmonics of these signals cannot be found.

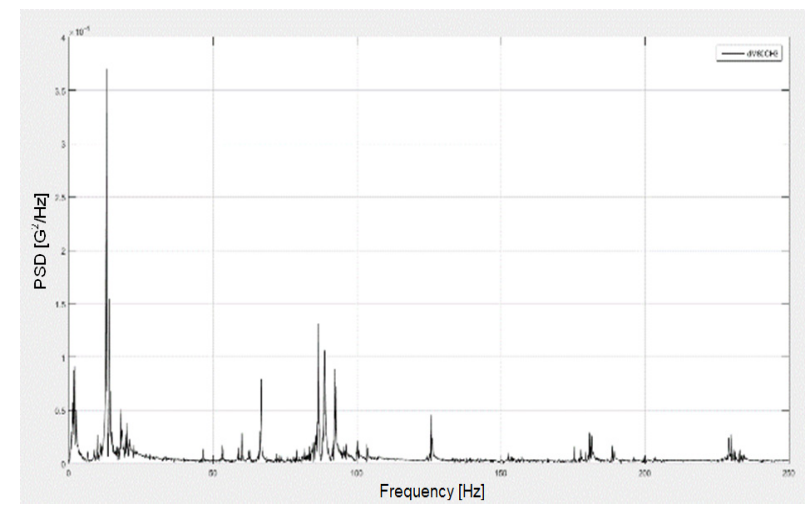

Figure 13. PSD recorded during running on a motorway at speed of $80 \mathrm{~km} / \mathrm{h}$

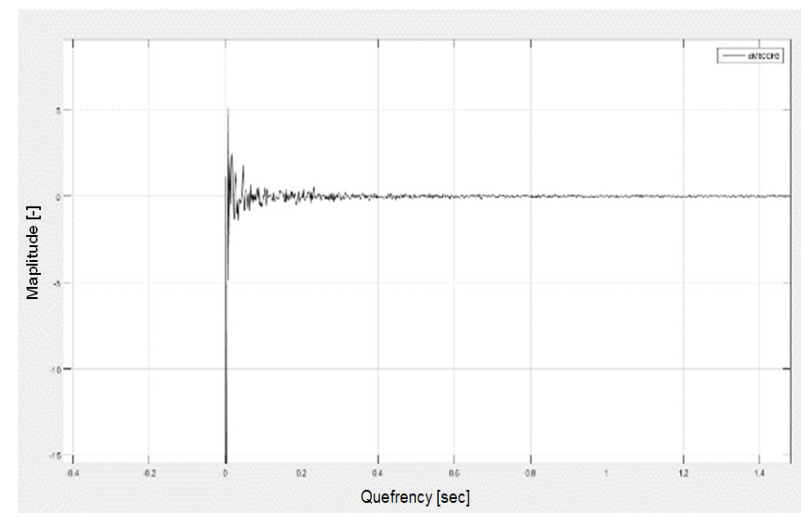

Figure 14. Cepstrum function formed from the PSD function shown in Figure 13.

In summary, from the cepstrum analysis it can be established that the exciting signals are originating from different outer sources and in higher frequency ranges no half-harmonics arise from them.

\section{CONCLUSION}

In the present study, the dynamic behaviour of the platform of semi-trailer truck was investigated and the following can be concluded:
No pure harmonic excitation is transmitted from the truck engine to the platform of the semi-trailer.

The longitudinal and lateral vibrations are not starting from value zero due to the fact that the semitrailer has got two different positions controlled by the air-suspension pressure for loading and travelling. It is 1-3 degrees horizontal and 1-2 degrees in lateral, depending on road condition, loading and actual payload.

The poor road conditions increase the PSD values by 4.3-5.1 times, values of low maplitude can be found up to value of $5 \mathrm{sec}$ quefrency, and this phenomenon is true for all variants of acceleration-time functions that were recorded.

Finally, the results of this paper can be applied for simulations on vibration tables. In this case, special attention must be paid to that that the simulated vibrations must not be stationary and in one way or another the base tilts of the platform must be taken into consideration due to the backwards and sidewards inclination angle of the platform.

\section{ACKNOWLEDGEMENT}

This work was supported by the project EFOP-3.6.1-162016-00017 of Széchenyi István University. The authors would also like to acknowledge the companies and partners (AUDI Hungaria Kft.) that allowed the measurements to be taken in their shipping environment.

\section{REFERENCES}

[1] Röbisch K.: Transportsicherer profitieren 2014 von geringen Schadenquoten, IUMI-Konferenz, Berlin, 2015

[2] Singh, S.P., Jarimopas, B., Saengnil, W.: Measurement and Analysis of Vibration Levels in Commercial Truck Shipments in Thailand and Its Impact on Packaged Produce, J. Test. Evaluat., Vol., No. 2, pp.1-7, 2006. doi: 10.1520/JTE14007

[3] Pidl, R.: Analytical approach to determine vertical dynamics of a semi-trailer truck from point of view of goods protection, AIP Conference Proceedings 1922, 120003, 2018, doi: 10.1063/1.5019118

[4] Singh SP, Marcondes J.: Vibration levels in commercial truck shipments as a function of suspension and payload. J. Test. Evaluat. Vol. 20, No. 6, pp. 466-469, 1992. doi:10.1520/JTE11941J

[5] Fragassa, C., Macaluso, I., Vaccari, M., Lucisano, G.: Measuring the mechanical and climatic conditions encountered by palletized products in handling and transport. FME Transactions, Vol. 45, No. 3, pp. 382-393, 2017. doi:10.5937/fmet1703382F

[6] Singh, J., Singh, S. P. and Joneson, E.: Measurement and analysis of US truck vibration for leaf spring and air ride suspensions, and development of tests to simulate these conditions. Packag. Technol. Sci., Vol. 19, No. 6, pp. 309-323, 2006 doi:10. 1002/pts.732

[7] Böröcz, P.: Vibration Levels in Vans as a Function of Payload and Leaf Spring Sheet Number. J. Test. 
Evaluat., Vol. 46, No. 1, pp. 236-243, 2018. doi: 10.1520/JTE20160538

[8] Zhou, R., Yan, L., Li, B., and Xie, J.: Measurement of Truck Transport Vibration Levels in China as a Function of Road Conditions, Truck Speed and Load Level. Packag. Technol. Sci., Vol. 28, No. 11, pp. 949-957, 2015. doi: 10.1002/pts.2176.

[9] Ilić, Z., Rašuo, B., Jovanović, M., Janković, D.: Impact of Changing Quality of Air/Fuel Mixture during Flight of a Piston Engine Aircraft with Respect to Vibration low Frequency Spectrum, FME Transactions, Vol. 41 No.1, pp. 25-32, 2013.

[10] Ilić, Z., Rašuo, B., Jovanović, M., Pekmezović, S., Bengin, A., Dinulović, M.: Potential Connections of Cockpit Floor - Seat on Passive Vibration Reduction at Piston Propelled Airplane, Technical Gazette, Vol.21, No.3, pp. 471-478, 2014.

[11]Böröcz, P.: Averaged vibration levels during courier parcel delivery service in small truck in Hungary, FME Transaction, Vol. 46, No. 2, pp.211217, 2018. doi:10.5937/fmet1802211B

[12] Matijević, D.V., Popović, V.M.: Overview of Modern Contributions in Vehicle Noise and Vibration Refinement with Special Emphasis on Diagnostics, FME Transactions, Vol. 45, No. 3, pp. 448-458. 2017.

[13]Ilić, Z., Rašuo, B., Jovanović, M., Jovic ić, S., Tomić, Lj., Janković, D., Petrašinović, D.: The Efficiency of Passive Vibration Damping on the
Pilot Seat of Piston Propeller Aircraft, Measurement, Vol. 95, pp. 21-32, 2017.

\section{ДИСКРЕТНА ФУРИЈЕОВА ТРАНСФОРМА- ЦИЈА И ЦЕПСТРУМ АНАЛИЗА ПОЈАВЕ ВИБРАЦИЈА КОД КАМИОНА СА ПОЛУ- ПРИКОЛИЦОМ}

\section{Р. Пидл, П. Бороц}

Рад приказује нову технику анализе вибрацијских сигнала у току транспорта и пружа нове инфор-мације инжењерима како би боље разумели ову физичку појаву. Један од главних извора оштећења у току транспорта су перманентне вибрације које се преносе са платформе полу-приколице на терет. Природа вибрација зависи од услова друма и карактеристика возила. У овом раду су анализиране вибрације код камиона са две осовине који вуче полу-приколицу са три осовине и има ваздушне амортизере. Фактори од утицаја на транспорт су тип друма (ауто-пут, пут првог, другог и трећег реда) и различита брзина возила. Вибрације су мерене на приколици и регистроване, а затим је извршена евалуација вредности у окружењу MATLAB. Присуство хармонијских компонената вибрација, стационарност облика режима, карактеристични фреквенцијски уски појасеви РМС и ПСД вредности су првенствено проучени. Примењене су следеће методе: дискретна Фуријеова трансформација, функције аутокорелације и унакрсне корелације и цепструм анализа. 